\title{
EXOTIC PLANTS IN HALIMUN SALAK CORRIDOR:MICRO-ENVIRONMENT, DETECTION AND RISK ANALYSIS OF INVASIVE PLANTS
}

\author{
DECKY INDRAWAN JUNAEDI ${ }^{1}$, DODO $^{2}$ \\ ${ }^{1}$ Cibodas Botanical Garden, Indonesian Institute of Sciences (LIPI), \\ PO. BOX 19 SDL Sindanglaya, Cipanas, Cianjur 43253, \\ ${ }^{2}$ Centre for Plant Conservation, Bogor Botanical Garden, Indonesian Institute of Sciences (LIPI)
}

Received 18 June 2013/Accepted 2 June 2014

\begin{abstract}
Research of exotic plant species detection and risk analysis of invasive plant was conducted in Halimun-Salak corridor area. This study aimed to conduct inventory of exotic plant species in this area and to perform risk analysis of invasive to the exotic plants found. The invasion risk assessment of detected exotic plants was analyzed using Weed Risk Assessment Procedure (WRAP) method. Moreover, analysis of multi-dimensional scaling (MDS) based on inequality was performed on relative humidity, light intensity, and soil $\mathrm{pH}$. There are eleven exotic plant species consisted of three tree species and eight species of herbs/shrubs. Austroeupatorium inulifolium and Camellia sinensis are the exotic species with the highest and the lowest WRAP score, respectively. MDS analysis shows that exotic tree species have similar environmental variables. Moreover, environmental variables of Clidemia birta are relatively different from other exotic species found in the Halimun-Salak corridor.

Recommendations for the management of invasive exotic plant species in the area are: immediate management implementation, priority of eradication to exotic plants that have not been abundant but have high risk score, two management options (gradual eradication or containment) should be considered for exotic plants with very high WRAP score, such as Ageratina riparia, Austroeupatorium inulifolium and Chromolaena odorata.
\end{abstract}

Key words: plant ecology, Halimun-Salak corridor, Multi-Dimensional Scaling, Weed Risk Assessment, invasive plant, conservation

*Corresponding author : deqee82@gmail.com 


\section{INTRODUCTION}

Halimun-Salak corridor ecosystem is important because it is not only a mountain forest ecosystem, but also acts as a connecting corridor between Mount Salak and Mount Halimun. Moreover, Halimun-Salak corridor has several risk factors associated with the threat to ecosystem integrity. Along with habitat degradation, fragmentation and disturbance from human activities, invasive alien species (IAS) (including invasive alien plants) being one of the factors that poses a threat to the integrity of the Halimun-Salak corridor ecosystem (JICA 2005). Within an 11 years period (19902001), the width of the Halimun-Salak corridor has decreased from $1.4 \mathrm{~km}(1990)$ to $0.7 \mathrm{~km}$ (2001) (Cahyadi 2003). On the other hand, there are lack of studies on invasive species in South East Asia, where the biodiversity hotspot lies in (Peh 2010).

Considering invasive species issues, detection and risk analysis of invasive plants are needed in the management of invasive plants. Upon the detection, alien species which potentially become invasive could be detected and managed earlier so that management cost becomes cheaper. By doing risk assessment, existed exotic plants, either invasive or not invasive can be estimated and ranked due to its invasiveness rates or invasiveness possibilities. Therefore, management prioritization of exotic invasive plants will be accomplished easier with risk assessment. Risk assessment reflects the chances of an exotic species to become invasive in the future or reflects the rate of invasiveness itself. Weed Risk Assessment Procedure (WRAP) (Virtue et al. 2008) is a risk assessment system used to assess the risk of invasive plant species from an exotic species that are already existed in a new host area.

The objective of this study was to conduct inventory of exotic plants (either invasive or not invasive (yet)) that are already existed in the Halimun-Salak corridor. This study also aimed to look at the risk of exotic plants to become invasive in the Halimun-Salak corridor. In addition, this study also aimed to analyze the diversity of habitat environment (micro-environment) variables $(\mathrm{pH}$, light intensity and air humidity) of areas where exotic species were detected.

\section{MATERIALS AND METHODS}

\section{Study site}

Halimun-Salak corridor is the area that connects Mount Salak and Mount Halimun. Halimun-Salak corridor included as a part of Halimun-Salak National Park based on Minister of Forestry Decree No. 175/Kpts-II/2003 dated June 10, 2003. Northern part of the corridor is part of administrative region of Bogor covering area as large as 1662.72 hectares. Southern part of the corridor is included in the district of Sukabumi which covered 2533 hectares. The altitude range of Halimun-Salak corridor is from $1000 \mathrm{~m}$ above sea level to $1400 \mathrm{~m}$ above sea level. Annual rainfall in the Halimun-Salak corridor ranges from $4000 \mathrm{~mm}$ to $5000 \mathrm{~mm}$ per year (JICA 2005). 


\section{Exotic plants detection}

Exotic species inventory was conducted at 27 observation points in 7 different locations in the Halimun-Salak corridor. Sampling areas covered by the detection sampling are: Bivak, Legok Buluh, Cigorowek-3, Palahlar, Pasir Panjang, Pasir Bedil and Kubang (Table 1).

Tabel 1. Detection sampling location in Halimun-Salak corridor

\begin{tabular}{|c|c|c|c|c|c|}
\hline \multirow{2}{*}{ Location } & \multicolumn{2}{|c|}{ Coordinates } & \multirow{2}{*}{$\begin{array}{c}\text { Altitude } \\
\text { (m asl) }\end{array}$} & \multirow{2}{*}{$\begin{array}{l}\text { Sampling } \\
\text { number }\end{array}$} & \multirow{2}{*}{$\mathrm{AR} / \mathrm{FI}$} \\
\hline & $\mathrm{S}$ & $\mathbf{E}$ & & & \\
\hline Bivak & $06^{044^{\prime} 59.8^{\prime \prime}}$ & $106^{036} 47.9^{\prime \prime}$ & 1100 & 6 & $\mathrm{AR}$ and $\mathrm{FI}$ \\
\hline Legok Buluh & $06^{044} 53.0^{\prime \prime}$ & $106^{0} 37^{\prime} 07.0^{\prime \prime}$ & 1068 & 6 & $\mathrm{AR}$ and $\mathrm{FI}$ \\
\hline Cigorowek-3 & $06^{04} 44^{\prime} 42.1^{\prime \prime}$ & $106^{0} 38^{\prime} 01.3^{\prime \prime}$ & 1015 & 4 & $\mathrm{AR}$ and $\mathrm{FI}$ \\
\hline Palahlar & $06^{04} 44^{\prime} 53.1^{\prime \prime}$ & $106^{03} 7^{\prime 22.6 "}$ & 1021 & 2 & $\mathrm{AR}$ \\
\hline Pasir Panjang & $06^{045^{\prime} 11.2^{\prime \prime}}$ & $106^{0} 37^{\prime} 12.6^{\prime \prime}$ & 1061 & 3 & $\mathrm{AR}$ and $\mathrm{FI}$ \\
\hline Pasir Bedil & $06^{045^{\prime}} 06.9^{\prime \prime}$ & $106^{0} 36^{\prime} 54.6^{\prime \prime}$ & 1069 & 2 & AR \\
\hline Kubang & $06^{04} 5^{\prime} 17.6^{\prime \prime}$ & $106^{0} 37^{\prime} 52.2^{\prime \prime}$ & 1042 & 4 & $\mathrm{AR}$ and $\mathrm{FI}$ \\
\hline
\end{tabular}

Notes: $\mathrm{AR}=$ adjacent to footpath, $\mathrm{FI}=$ forest interior

Detection samplings were conducted in two types of locations. The first location type is the area adjacent to forest access road into the woods with the assumption that the exotic species introduction pathway is via humans (carried away to the forest by humans). The second location type is the area inside the forest interior with the assumption that in addition to human pathways, exotic species can also be dispersed by the help of animals, wind and other vectors.

At each sampling point, exploratory observation of the exotic plant species was conducted within a radius of 3 meters from the point of observation. Exotic plant species were observed and recorded.

\section{Invasiveness risk assessment}

Exotic plants that have been detected were then assessed by using Australia Weed Risk Assessment Procedure (WRAP) (Virtue et al. 2008) to assess the risk of invasiveness. WRAP is a framework used to analyze the risk of an invasive exotic plant that are already existed in an invaded area. WRAP consists of questions that should be answered and then scoring was performed based on the answers. The scoring decision was conducted fully based on available scientific information provided from online global invasive plant database such as Pacific Island Ecosystem at Risk (PIER) and Invasive Species Specialist Group (ISSG), IUCN database. Total accumulated value of all WRAP scoring answer was expressed as a risk score. The risk scores are quantitative and can be compared between one species and another in the analysis. WRAP used in this study were adapted and modified to match the conditions and circumstances in 
the study locations as provided in Annex 1. Accuracy of the risk assessment results is measured using logistic regression analysis to generate the ROC curve (receiver operating characteristic, using MYSYSTAT 13) that describes how accurate risk analysis model used (Quinn \& Keough 2002). Logistic regression follows the equation:

$\Pi(\mathrm{x})=\mathrm{e}^{\mathrm{g}(\mathrm{x})} /\left(1+\mathrm{e}^{\mathrm{g}(\mathrm{x})}\right)$

where: $\mathrm{g}(\mathrm{x})=\beta 0+\beta 1$ (WRAP score) and $\Pi$ (x) is the opportunity of exotic species (i) will become invasive. Definition of invasive exotic plants obtained (real data) was defined as the relative frequency $(\mathrm{FR})$ more than $10 \%$.

\section{Micro-environment}

On every detection sampling plot, ecological (micro-environment) data were recorded for analysis of ecological habitats. Habitat ecological data recorded include: air relative humidity, light intensity, and soil $\mathrm{pH}$. Analysis of multi-dimensional scaling (MDS) was based on inequality using XLSTAT software (Microsoft Excel add-in) and was conducted based n micro-environment data. MDS analysis was used to examine the degree of differences among detected exotic species based on its microenvironment/ micro-habitat variables measured.

\section{RESULTS AND DISCUSSION}

Based on the sampling detection of exotic plants in 27 locations of the study site, species area curve is presented in Figure 1. The curve indicates the relation between the numbers of sampling plots which was taken with the addition of new exotic species detected.

Detected exotic plants in the Halimun-Salak corridor based on modified WRAP scoring results are presented in Table 2.

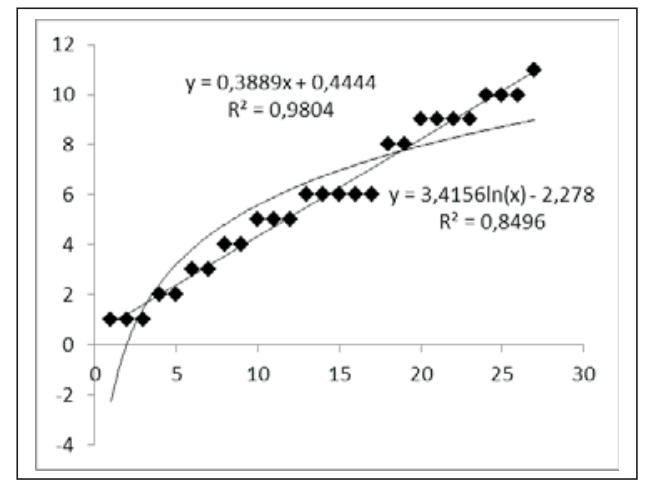

Figure 1. Species-sampling relation curve that describes the relation between the number of sampling ( $\mathrm{x}$ axis) and new exotic species counted (y axis) 
BIOTROPIA Vol. 21 No. 1, 2014

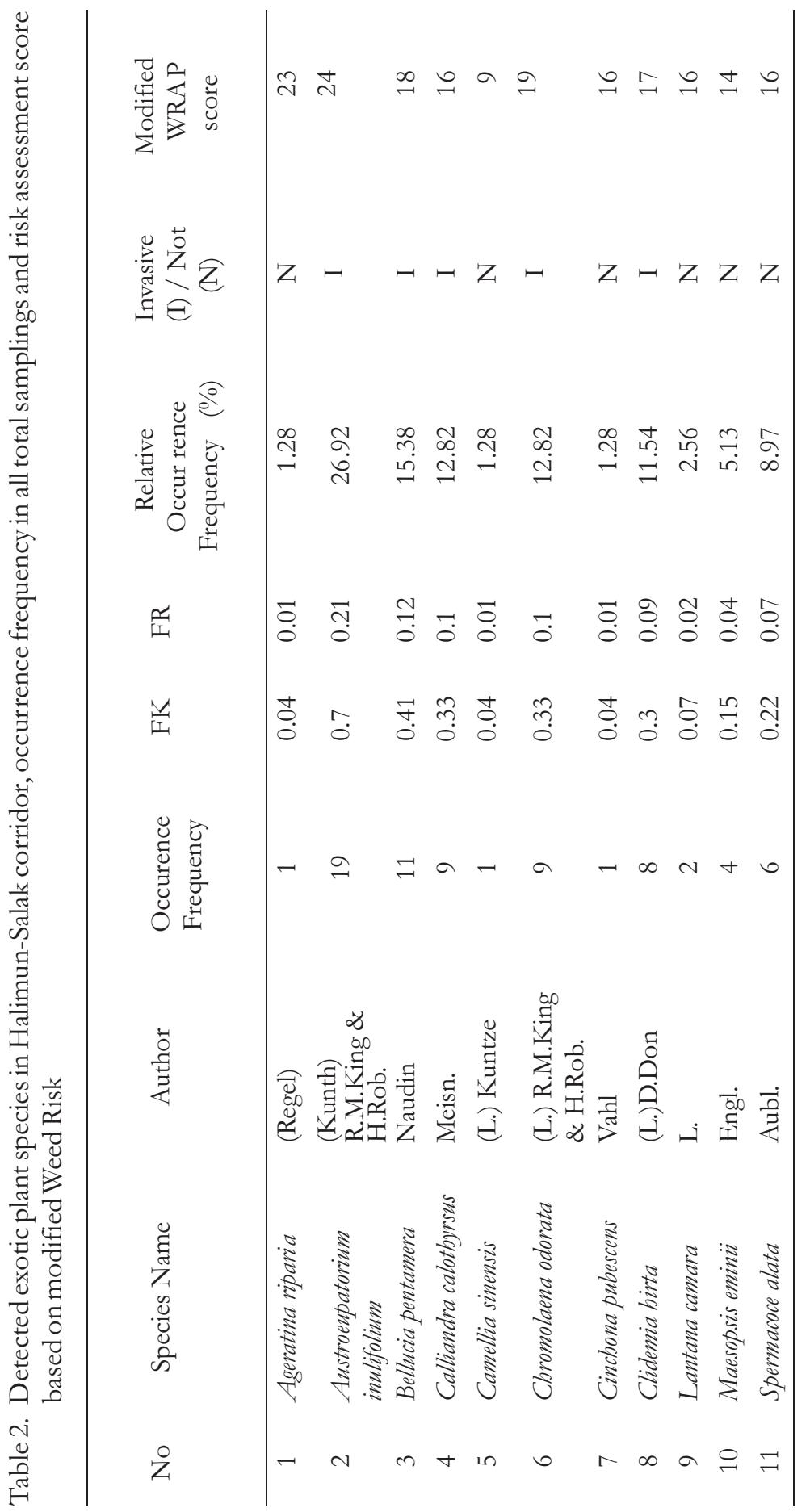


ROC curves that illustrate the accuracy of the risk analysis model are presented in Figure 2 . The value of area under the ROC curve is 0.817 . This value showed that the accuracy of the logistic regression model is approximately $81.7 \%$

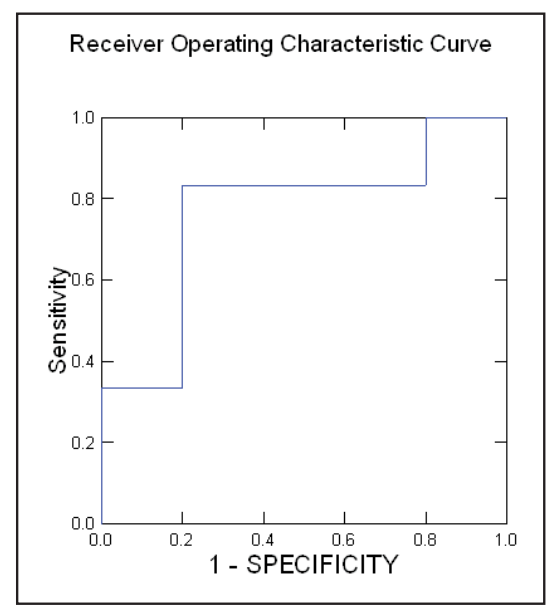

Figure 2. ROC (receiver operating characteristic) curve that determines the accuracy of the logistic regression conducted in the risk assessment

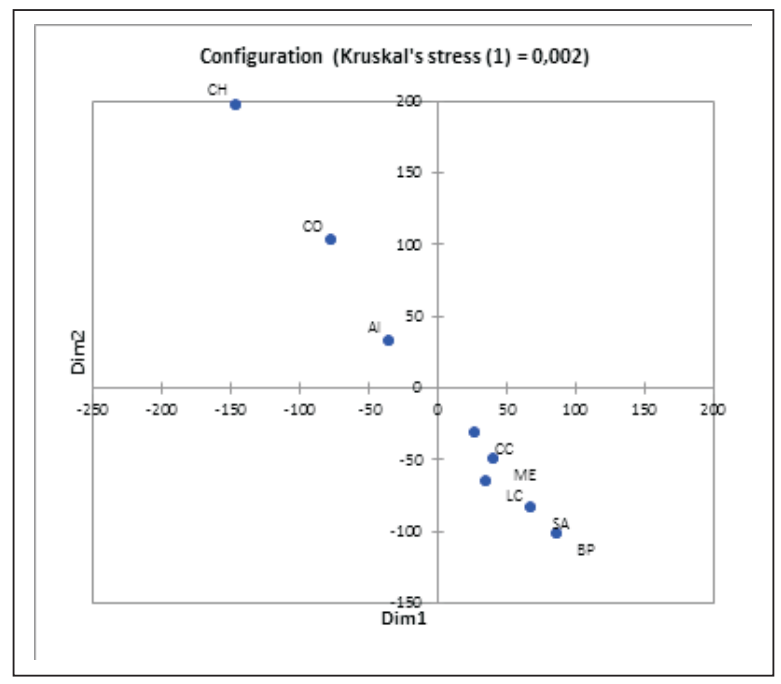

Figure 3. MDS configuration of three environment variables of detected exotic plants: soil $\mathrm{pH}$, light intensity and air humidity. Dimension 2 was used in the configuration. Detected exotic species are, AI: Austroeupatorium inulifolium, BP: Bellucia pentamera, CC: Calliandra calotbyrsus, CO: Chromolaena odorata, CH: Clidemia hirta, LC: Lantana camara, ME: Maesopsis eminii and SA: Spermacoce alata 


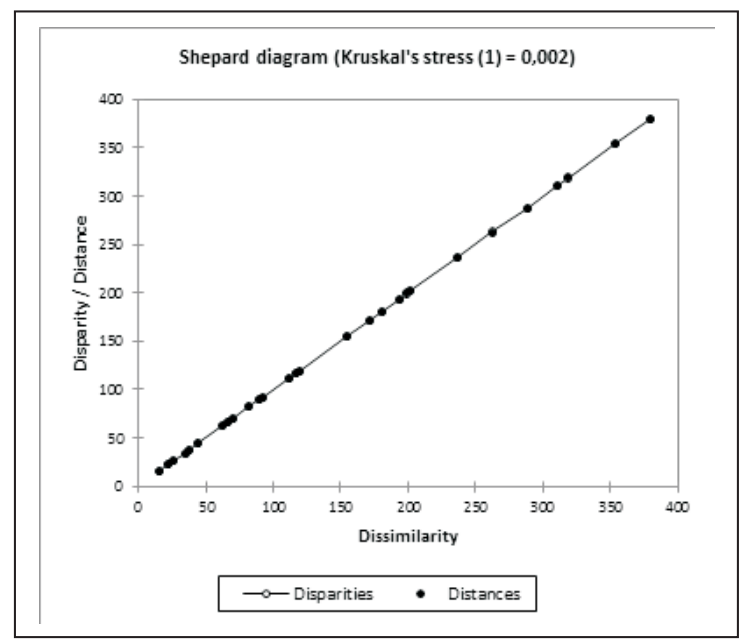

Figure 4. Shepard diagram of MDS analysis of three environment variables: soil $\mathrm{pH}$, light intensity and air humidity

MDS analysis results based on three environmental variables ( $\mathrm{pH}$, light intensity and air humidity) are presented in Figure 3. Kruskal stress value of 0.002 indicates that the model configuration presented in Figure 3 is valid. The valid Kruskal stress value is smaller than 0.1 (Quinn \& Keough 2002).

Shepard diagram of MDS analysis is presented in Figure 4. Shepard diagram indicates the reliability of the data used in the MDS analysis.

Based on the detection results, from totally 11 exotic species detected, four of them are tree species: Maesopsis eminii, Cinchona pubescens, Calliandra calothyrsus and Bellucia pentamera. The rest of other seven species are herbaceous/shrubs. Based on detection sampling data, two exotic tree species having FR value above $10 \%$ are Bellucia pentamera and Calliandra calothyrsus. Bellucia pentamera is native to South America (Backer \& Backhuizen 1963). This plant is likely to spread rapidly in the HalimunSalak corridor because of rapid spread through the animal's assistance that eats the fruit.

Exotic species can become invasive when it got past the "barrier" that exists in the invaded locations (Theoharides \& Dukes 2007). In general, exotic plants have become invasive when it is said to have had offspring and form new colonies that are relatively numerous and have an adverse impact to invaded ecosystems (Richardson et al. 2000). However, not all exotic species detected are able to reach interior part of the forest where the forest canopy cover is still relatively intact. Most of the exotic plants of the Asteraceae found in the exterior forest areas or in the forest gaps (forest openings). MDS analysis showed that two Asteraceae species (C. odorata and $A$. inulifolium) have different positions relative to the other exotic species due to different types that formed on the configuration. The different position in the MDS 
configuration refers to different micro-environment preferences. Therefore, $C$. odorata and $A$. inulifolium have relatively different micro-environment preferences compared to other exotic plants that are clustered in different quadrants (Fig. 3). Even though $A$. inulifolium has the highest WRAP value and refers to high risk to become invasive, but the environmental constraints (the intensity of light/canopy shade availability) becomes the limiting factor for these two species to become very invasive. However, if there is a gap occurred in the forest area, this species will be able to establish and invade.

Another interesting point is the grouping of exotic tree species in the same quadrant of the MDS analysis result (Maesopsis eminii, Calliandra calothyrsus and Bellucia pentamera) (Fig. 3). Habitat preference (relative humidity, light intensity, and soil $\mathrm{pH}$ ) were similar among these three exotic tree species in Halimun-Salak corridor. These three exotic tree species were mostly found in the interior forest, not in the forest edges. Indeed, these three exotic tree species have not reached invasive stage. However, after a period of adaptation time (lag time), these species will quickly become invasive and will have an impact on the Halimun-Salak corridor ecosystem. Time lag determines exotic plant species to become invasive (Hobbs \& Humpries 1995). IAS management in Halimun-Salak corridor should be focused on species that are already existed in the forest interior. Effective and efficient management can minimize the cost of subsequent management (Radosevich 2007).

Clidemia hirta's micro-environment preference (three variables: soil $\mathrm{pH}$, light intensity and relative humidity) is very different from almost all exotic species recorded. Backer and Backhuizen (1963) mentioned that C. birta naturalized in West Java, especially around Bogor. In its native range in South America and the Caribbean, C. hirta dominates open areas, forest edges and forest openings / disturbed forest and is rarely found under the shade-covered forests floor (DeWalt et al., 2004). But DeWalt et al. (2004) also have indicated that $C$. hirta is more shade tolerant in the invasion region than in the native range. C. hirta included as one of the 100 worst invasive species in the world (ISSG 2006).

Ageratina riparia and Lantana camara is an interesting case in this study. WRAP values of $A$. riparia and $L$. camara are relatively high, while the results of the detection sampling populations is relatively low (Table 2). There are several factors that may explain the low number of sampling populations of A. riparia and L. camara. First, the number of sampling may be relatively small compared to the pattern of spread of this species in the Halimun-Salak corridor. With the equal number of sampling units, the representation of the types of populations obtained with the clumped distribution pattern is more adequate than diffuse or random dispersal patterns. Secondly, $L$. camara is not (or not yet?) penetrating the ecological constraints that exist in the Halimun-Salak corridor forest to reach the invasive stage. L. camara is still in the process of establishment/early naturalization stage. L. camara naturally occurs in open areas and the seed germination is inhibited by low light intensity (Gentle \& Duin 1997, 1998). 


\section{CONCLUSIONS}

There are 11 species of exotic plants in the Halimun-Salak corridor area consisted of three woody tree species and eight herbs/shrubs species. Lantana camara is an exotic species that has the largest WRAP value (24) and Camellia sinensis is an exotic species with the lowest WRAP value (-4). Exotic tree species have similar environmental preferences. Clidemia hirta is an exotic species that has relatively different environment variables compared to other exotic species found in the Halimun-Salak corridor.

Based on the risk assessment of invasiveness and field observation conducted, some recommendations for the management of invasive exotic plant species in the Halimun-Salak corridor are: (1) management of invasive species can be done with several options, but the more immediate the implementation, the cheaper the management cost and the simpler the management methods will be, (2) eradication can be implemented to exotic plant species that have not been abundant in population but have relatively high WRAP value such as Bellucia pentamera and Cinchona pubescens. Whenever possible, eradication should start from the individual which exist in the forest interior and continue toward the outside of the forest, (3) Gradual eradication or control (containment) are two possible management options for exotic plant species that have a very high WRAP score such as Ageratina riparia, Chromolaena odorata and Lantana camara.

Future study should be focused on how to conduct IAS management implementation that gives the smallest impact to the ecosystem of Halimun-Salak corridor. It is important to conduct ecological study of exotic species micro-habitat as well as investigating the impact of these exotic species to Halimun-Salak corridor ecosystem.

\section{ACKNOWLEDGEMENTS}

Authors thank Soekisman Tijtrosoedirdjo for significant recommendations and review on the methodology section of this work. Authors also thank Sri Astutik for valuable discussion during field data collection, Megawati for dedicated plant identification and to Pak Uci and Pak Atma for their field assistance and guidance. This study funded by grant "Program Prioritas Nasional 9 Program Penelitian, Penguasaan, dan Pemanfaatan Iptek: Pembangunan Kebun Raya Daerah" (National Priority Program, 9 Programs for Research, Control, and Utilization of Science and Technology on the Development of District Botanical Garden).

\section{REFERENCES}

Backer CA, Backhuizen RCVDB. 1963. Flora of Java (Spermatophytes only) volume I. Groningen: N.V.P. Nordhoff. 
Cahyadi I. 2003. Analisis Spasial Struktur dan Fungsi Koridor Hutan antara Taman Nasional Gunung Halimun dengan Hutan Lindung Gunung Salak. Bogor: Program Pascasarjana IPB, Tesis.

DeWalt SJ, Denslow JS, Ickes K. 2004. Natural-enemy release facilitates habitat expansion of the tropical shrub Clidemia hirta. Ecology 85(2): 471-483.

Gentle CB, Duggin JA. 1997. Lantana camara L. invasions in dry rainforest - open forest ecotones: The role of disturbances associated with fire and cattle grazing. Australian Journal of Ecology 22: 298-306.

Gentle CB, Duggin JA. 1998. Interference of Choricarpia leptopetala by Lantana camara with nutrient enrichment in mesic forests on the Central Coast of NSW. Plant Ecology 136: 205-211.

Heikkila J. 2011. A review of risk prioritisation schemes of pathogens, pests and weeds: principles and practices. Agricultural and Food Science 20: 15-28.

Hobbs RJ, Humphries SE. 1995. An integrated approach to the ecology and management of plant invasions. Conservation Biology 9: 761-770.

Invasive Species Specialist Group (ISSG). 2006. Global Species Invasive Database: Clidemia hirta. Accessed 10 January 2013 from http://www.issg.org/database/species/ecology.asp?si=53\&fr=1\&sts=sss\& lang ENN.

JICA Team, Endangered Species. 2005. Ecological Study Halimun-Salak Corridor Mount Halimun-Salak National Park. Accessed 10 September 2011 from http://sci.kagoshima-u.ac.jp.

Peh KSH. 2010. Invasive species in Southeast Asia: the knowledge so far. Biodiversity and Conservation 19: 1083 1099

Quinn GP, Keough, MJ. 2002. Experimental Design and Data Analysis for Biologist. Cambridge: Cambridge University Press.

Richardson DM, Pysek P, Rejmanek M, Barbour MG, Panetta FD, West, CJ. 2000. Naturalization and invasion of alien plants: concepts and definitions. Diversity and Distributions 6: 93-107.

Radosevich, SR 2007, Plant invasions and their management, chapter 3 in CIPM (ed.), Invasive plant management: CIPM online textbook, Bozeman, MT: Center for Invasive Plant Management. Accessed 2 May 2011 from http://www.weedcenter.org/textbook/index.html.

Theoharides KA, Dukes JS. 2007. Plant invasion across space and time: factors affecting nonindigenous species success during four stages of invasion. New Phytologist 176: 256-273.

Virtue S, Spencer, RD, Weiss, JE, Reichard, SE. 2008. Australia's Botanic Gardens weed risk assessment procedure. Plant Protection Quarterly 23: 166-178. 


\section{Annex 1. Modified Weed Risk Assessment Procedure used in the study (Virtue et al 2008)}

\begin{tabular}{lc}
\hline \multicolumn{1}{c}{ IMPACTS } & SCORE \\
\hline 1. WEED HISTORY - What is the weed history of the plant? & 4 \\
\hline It is a weed in your region & 3 \\
- It is a weed elsewhere in Indonesia & 2 \\
It is a weed overseas & 1 \\
genus are weeds in Indonesia and/or overseas & 0 \\
\hline
\end{tabular}

\section{COMPETITION - How well does the plant out-compete other types of plants?}

- If not controlled it can grow to dominate the following three size classes of plants:

trees (or emergent aquatics)

shrubs (or surface aquatics)

ground covers (or submerged aquatics)

- If not controlled, it can grow to dominate one of the above size classes of plants. OR

at certain times of the year it can dominate two size classes

- If not controlled, it can dominate one of the above size classes at certain times of the year

- It is not competitive, and is readily dominated by most other plants if they are not controlled

3. HEALTH - Is the plant a health risk to people and/or animals?

- Is it highly toxic and has caused deaths

- It can cause significant physical injuries or illness

- It can cause slight physical injury or mild illness with no longlasting effects

- It is not a health risk to animals or humans

4. MOVEMENT - If the plant escapes does it have the potential to block the movement of people, animals, vehicles or water?

- A group of plants is very tall, thorny, tangled and/or dense \& impenetrable year-long

- A group of plants is rarely impenetrable, but does significantly undergo slow physical movement year-long

- A group of plants is never impenetrable but can significantly undergo slow movement for part of the year 


\section{Annex 1. Continued}

\section{IMPACTS}

SCORE

5. ENVIRONMENTAL EFFECTS - Does the plant have attributes that, at high density, can
cause detrimental changes to the environment?

- The plant has two or more of the following attributes:

highly flammable leaves
salty leaves
animal invasion
high water use
removes habitat or food source for native animals

- It has one of the above attributes

- It has none of the above attributes

6. EASE OF CONTROL - How easy is the plant to kill?

- Hard. It readily tolerates or reshoots after herbicide application, cutting, cultivation, grazing or fire

- Medium. One herbicide application or cultivation kills the plant, but not cutting, grazing or fire

- Simple. Plants are killed by hand-pulling, cutting, grazing or fire

\section{POTENTIAL DISTRIBUTION}

7. HARDINESS - How well is the plant adapted to the local climate?

- In the garden it needs no maintenance to establish, grow and fbwer, if planted at the right time of year. The localclimate is similar to other places where it grows in the world. OR, it is a weed of drier, exposed land in the region or in other parts of Indonesia or overseas with similar climate types

- It needs some maintenance to establish when planted in the garden, but will then grow and flower well without further maintenance. The local climate is harsher in some aspects to what the plant is originally adapted to. OR, it is a weed of wetter, sheltered land in the region or in other parts of Indonesia or overseas with similar climate types

- It needs some maintenance to establish when planted in the garden, but can then survive unassisted. However, it grows poorly in the local climate and needs occasional maintenance during stressful periods (e.g. watering in dry months). OR, it has naturalised occasionally in the region in specialist habitats (i.e. it has a narrow ecological amplitude) but hasn't formed high-density infestations. It grows in distinctly different climates elsewhere in Indonesia or overseas

- It needs frequent maintenance and/or special conditions to grow and flower in the garden. OR, the local climate isvery different to where the plant grows elsewhere in the world and it has not been recorded as naturalised in the region or in other parts of Indonesia or overseas with similar climate types 


\section{Annex 1. Continued}

\section{INVASIVENESS}

8. REPRODUCTION - How well does the plant reproduce?

- The plant has all three of the following attributes:

short time to seeding (within 3 years from panting for herbaceous plants, 5 years for woody plants)

'volunteer' seedlings commonly come up in the garden, OR as a weed,

seedlings are commonly seen nearby mature plants.

mature plants produce at least 5 new plants by vegetative means per year

- It has two of the above attributes

- It has one of the above attributes

- It has none of the above attributes, but is able to reproduce by itself

- It sets no seed in any natural circumstances and has no vegetative spread. The plant can only be propagated with human assistance (eg. shoot cuttings). It will not naturalise. (LOW WEED RISK)

9. NATURAL SPREAD - Are the plant's propagules (seed or vegetative) likely to spread long distances to susceptible habitats by natural means?

- Propagules are likely to be dispersed by two or more of the following:

flying animals ground animals water wind

AND susceptible habitats (e.g., farmland, native vegetation, road and rail corridors, waterways) are within $1 \mathrm{~km}$ of the gardens

- Propagules are likely to be dispersed by two or more of the above means AND susceptible habitats are within $5 \mathrm{~km}$ of the gardens, OR, Propagules are likely to be dispersed by one of the above means AND susceptible habitats are within $1 \mathrm{~km}$ of the gardens

- Propagules are likely to be dispersed by one of the above means AND susceptible habitats are within $5 \mathrm{~km}$ of the gardens

- Propagules are not normally spread long distances from parent plants BUT the Botanical Garden abuts susceptible habitats

- Propagules are not normally spread long distances from parent plants and the Botanical Garden is buffered from susceptible habitats by urban development

10. HUMAN SPREAD - Are the plant's propagules (seed or vegetative) likely to spread long distances due to human activities?

- The plant is appealing and easily to propagate. Visitors to the gardens may intentionally take propagules (e.g., seeds, cuttings, fruit etc.) to grow elsewhere

- Propagules are likely (or known) to be dispersed by two or more of the following means:

people (accidentally) vehicles/machinery contaminated produce in soil

- Propagules are likely (or known) to be dispersed by one of the above means

- Propagules are not normally spread long distances from the parent plant 
Exotic Plants in Halimun Salak Corridor - Decky Indrawan Junaedi et al.

Annex 2. Detection sampling data from 27 plots.

\begin{tabular}{|c|c|c|c|c|c|c|}
\hline Date & $\begin{array}{c}\text { plot } \\
\text { number }\end{array}$ & species name & $\begin{array}{c}\text { Altitude } \\
\text { (m asl) }\end{array}$ & $\begin{array}{l}\text { soil } \\
\mathrm{pH}\end{array}$ & $\begin{array}{c}\text { air relative } \\
\text { humidity } \\
(\%)\end{array}$ & $\begin{array}{c}\text { light } \\
\text { intensity (X } \\
2000 \text { lux) }\end{array}$ \\
\hline \multirow[t]{8}{*}{$20 / 06 / 2012$} & 1 & Austroeupatorium inulifolium & 1110 & 6 & 50 & 322 \\
\hline & 2 & Austroeupatorium inulifolium & 1103 & 6.2 & 55 & 219 \\
\hline & 3 & Austroeupatorium inulifolium & 1100 & 6.8 & 56 & 1270 \\
\hline & 4 & Austroeupatorium inulifolium & 1100 & 6.8 & 56 & 1270 \\
\hline & & Calliandra callothyrsus & & & & \\
\hline & 5 & Calliandra callotbyrsus & & & & \\
\hline & & Austroeupatorium inulifolium & & & & \\
\hline & 6 & Bellucia pentamera & & & & \\
\hline \multirow[t]{14}{*}{$21 / 06 / 2012$} & 7 & Austroeupatorium inulifolium & 1050 & 6 & 43 & 62 \\
\hline & & Bellucia pentamera & & & & \\
\hline & 8 & Spermacoce alata & 1068 & 6.8 & 52 & 594 \\
\hline & & Austroeupatorium inulifolium & & & & \\
\hline & & Bellucia pentamera & & & & \\
\hline & 9 & Austroeupatorium inulifolium & 1019 & 6.5 & 47 & 364 \\
\hline & & Calliandra callothyrsus & & & & \\
\hline & 10 & Maesopsis eminii & 1056 & 6 & 51 & 433 \\
\hline & & Maesopsis eminii & & & & \\
\hline & 12 & Austroeupatorium inulifolium & 1099 & 6.8 & 37 & 1010 \\
\hline & & Spermacoce alata & & & & \\
\hline & & Maesopsis eminii & & & & \\
\hline & & Bellucia pentamera & & & & \\
\hline & & Austroeupatorium inulifolium & & & & \\
\hline \multirow[t]{7}{*}{$23 / 06 / 2012$} & 13 & Chromolaena odorata & 1046 & 6 & 49 & 209 \\
\hline & & Bellucia pentamera & & & & \\
\hline & 14 & Bellucia pentamera & 1014 & 6.2 & 49 & 219 \\
\hline & & Calliandra callotbyrsus & & & & \\
\hline & 15 & Calliandra callothyrsus & 1041 & 6 & 51 & 697 \\
\hline & & Bellucia pentamera & & & & \\
\hline & 16 & none & 1003 & 6.5 & 55 & 267 \\
\hline \multirow[t]{6}{*}{$24 / 06 / 2012$} & 17 & Austroeupatorium inulifolium & 1005 & 6.5 & 50 & 3390 \\
\hline & & Chromolaena odorata & & & & \\
\hline & & Bellucia pentamera & & & & \\
\hline & 18 & Austroeupatorium inulifolium & 1049 & 6 & 51 & 1627 \\
\hline & & Lantana camara & & & & \\
\hline & & Clidemia birta & & & & \\
\hline
\end{tabular}


BIOTROPIA Vol. 21 No. 1, 2014

Annex 2. Continued

\begin{tabular}{|c|c|c|c|c|c|c|}
\hline Date & $\begin{array}{c}\text { plot } \\
\text { number }\end{array}$ & species name & $\begin{array}{c}\text { Altitude } \\
\text { (m asl) }\end{array}$ & $\begin{array}{l}\text { soil } \\
\mathrm{pH}\end{array}$ & $\begin{array}{c}\text { air relative } \\
\text { humidity } \\
(\%)\end{array}$ & $\begin{array}{c}\text { light } \\
\text { intensity (X } \\
2000 \text { lux) }\end{array}$ \\
\hline & & Chromolaena odorata & & & & \\
\hline & & Spermacoce alata & & & & \\
\hline \multirow[t]{10}{*}{$25 / 06 / 2012$} & 19 & Lantana camara & 1036 & 6.2 & 57 & 90 \\
\hline & & Clidemia birta & & & & \\
\hline & & Spermacoce alata & & & & \\
\hline & & Austroeupatorium inulifolium & & & & \\
\hline & & Chromolaena odorata & & & & \\
\hline & 20 & Cinchona succirubra & 1028 & 6.5 & 57 & 8.6 \\
\hline & & Bellucia pentamera & & & & \\
\hline & 21 & Austroeupatorium inulifolium & 1010 & 6 & 58 & 6.1 \\
\hline & & Chromolaena odorata & & & & \\
\hline & & Bellucia pentamera & & & & \\
\hline \multirow[t]{8}{*}{$26 / 06 / 2012$} & 22 & Austroeupatorium inulifolium & 1061 & 6 & 47 & 29 \\
\hline & & Calliandra callothyrsus & & & & \\
\hline & & Clidemia birta & & & & \\
\hline & & Chromolaena odorata & & & & \\
\hline & & Spermacoce alata & & & & \\
\hline & 23 & Austroeupatorium inulifolium & 1020 & 6.4 & 50 & 1311 \\
\hline & & Clidemia birta & & & & \\
\hline & & Bellucia pentamera & & & & \\
\hline \multirow{16}{*}{$27 / 06 / 2012$} & 24 & Calliandra callothyrsus & 1028 & 6.8 & 45 & 1590 \\
\hline & & Austroeupatorium inulifolium & & & & \\
\hline & & Camellia sinensis & & & & \\
\hline & & Clidemia birta & & & & \\
\hline & & Spermacoce alata & & & & \\
\hline & & Chromolaena odorata & & & & \\
\hline & 25 & Maesopsis eminii & & & & \\
\hline & & Austroeupatorium inulifolium & & & & \\
\hline & & Clidemia birta & & & & \\
\hline & 26 & Calliandra callotbyrsus & 1028 & 6.8 & 45 & 1590 \\
\hline & & Clidemia birta & & & & \\
\hline & 27 & Austroeupatorium inulifolium & 1028 & 6.8 & 45 & 1590 \\
\hline & & Calliandra callotbyrsus & & & & \\
\hline & & Clidemia birta & & & & \\
\hline & & Chromolaena odorata & & & & \\
\hline & & Ageratina riparia & & & & \\
\hline
\end{tabular}

